\title{
A Study on Technical High School Teachers' Views Concerning Corporal Punishment
}

\author{
Said Taş \\ Faculty of Education, Suleyman Demirel University, Turkey
}

Copyright $(2016$ by authors, all rights reserved. Authors agree that this article remains permanently open access under the terms of the Creative Commons Attribution License 4.0 International License

\begin{abstract}
Corporal punishment is defined as inflicting pain on body of someone who presents undesired behavior or does not present expected behavior. In the developed world, experiencing information society, corporal punishment is still in the agenda in educational system in Turkey. In this study, it was aimed to determine technical high school teachers' attitudes concerning corporal punishment in terms of various variables. The research is in scan type and a descriptive study. The research universe consists of the teachers who work at Technical High schools in Isparta, Antalya and Burdur in 2015-2016 semester. The research sample is 160 teachers who work at eighteen different schools which are at low, medium and high socio economic levels at research universe. In the research, the scale which is developed by Gözütok[4], is used to determine teachers' attitudes concerning corporal punishment. For analyzing data, for independent groups, t test and one way variance analysis are used. According to the research results; significant differences have been found out between technical school teachers' attitude towards physical punishment in terms of the socio-economic level of the schools where they work, their working years, and their gender. However, not an important difference has been found out between the attitude of teachers towards physical punishment in terms of the factors which are their marital status, having children and their class size.
\end{abstract}

Keywords Classroom Management, Correcting Undesired Behaviors, Corporal Punishment, Teachers' Attitudes

\section{Introduction}

Schools are the official institutions established in order for students to socialize. A number of components are available in school; namely, the administrator, teachers, students, curriculum, non-academic staff, buildings, teaching aids and materials, and the environment [1]. The most critical of those variables is the teacher. The teacher is responsible for organizing and conducting the processes required for an effective classroom and school management. Teachers' behaviors are important in students' achievement during and following school time. Teachers' task in school is to make the circumstances of external environment easier to students and to purify students' behaviors, and to secure the balance in school which is lacking in society by preventing the spread of easily encountered undesired behaviors into the school [2].

Some behaviors of teachers effect on these tasks positively but some of them affects negatively. Harsh, hard, humiliating, impolite and involving in corporal punishment behaviors have destructive effects on students, favorable learning environment and tasks of teachers. Corporal punishment is defined as inflicting pain in someone's body who doesn't display desired behaviors or displays undesired behaviors $[3 ; 4 ; 5 ; 6 ;]$. Benetar[5] defines physical punishment is the situations ranging from forcing someone to do something or tormenting resulting in lameness. Physical punishment is such punishment as hitting a child with hand, with a stick, belt or another object, kicking, shaking, pushing or pinching the child, or hurting him or her by pulling the ear or hair $[3 ; 4 ; 5 ; 6 ;]$. Apart from those, Gözütok[4] points out that punishment techniques such as throwing pieces of chalk or a duster and banging children's head onto the desk are also currently applied by teachers.

Flexible, broadminded, encouraging behaviors of teacher have beneficial influence on students. A teacher should actualize the learning behaviors in students which will assure affection, self- confidence and confidence in others, self-expression, consciousness of responsibility and which will enable them to shape and to internalize life Güven[7] suggests that the fundamental condition of effective learning is the carefully and well-designed learning experiences.

Therefore, it is important that the teacher know the social characteristics of the classroom, the group's influence of applying social pressure, and the students developmental properties. The most influential of all in students in the learning-teaching environment is the teacher's attitudes in class and his ability in classroom management $[8 ; 9 ; 10 ; 11]$. 
It is expected that the teacher, who is in charge of classroom management, must display students the desired behaviors in class and thus to set them a model.

In order for a teacher to demonstrate his students the desired behaviors, he should know of his students. So as to know the students adequately, a teacher should know about such things as their interests and abilities, achievements and failures, their levels of personal and social adjustment, their problems, strengths and weaknesses, value judgments, and the prohibitive as well as formative properties of the native environment in details . Each child is the outcome of their genetic characteristics and of the environment as well as people in contact. Teachers can learn soon that students in class are distinct from one another in many respects. The teacher who regards the differences and who undertakes the task of developing teaching strategies accordingly [12] is a competent, specialist teacher.

In our century, when information spreads very quickly, it is really engrossing to find that corporal punishment is still on the agenda while discussing such issues as distant education, multiple intelligences, individual education, and qualified teacher behaviors. The number of teachers considering corporal punishment as an instrument of discipline in some of the technical education institutions is not too few. Roll calling in workshop classes is performed in military manner by asking the students to stand in a queue and count as one, two, three, etc loudly by turning their faces. Unthinkable physical punishment such as beating the students with cables or other objects in the workshop is applied.

The majority of teachers and administrators do not have sufficient knowledge concerning the effects of corporal punishment on students [13]. Teachers believe that punishment is the best way to motivate students into behaving in the appropriate manner. They think that students perform the right behavior since the wrong one stops for a moment due to the punishment; however, they are mistaken. The long term outcome of punishment is revolt or obedience [14]. If applied by teachers as a method of sustaining discipline, such long term outcomes as undesired behaviors, aggression, behaviors of violence and judicial punishment, loss of learning and high risk of depression may arise [15; 16]. Physical punishment leads to a fall in students' mental activities, escaping from school, increase in revolt behaviors, loss of learning, personality problems and loss of self-reliance $[5 ; 17 ; 18]$. If a list is ordered according to researches for consequences, these will be like that;

a) Physical punishment may be a risk factor in terms of bodily exploitation [19].

b) This form of punishment increases the number of aggressive and inappropriate behaviors on the part of students [20].

c) The potential of developing anti-social behaviors of students exposed to physical punishment is quite high [21]. Students constantly exposed to such punishment display cowardice or aggression- the two extreme behaviors [22].

d) The practice of physical punishment teaches that giving pain to others is normal, contrary to the desired result.

e) Correlations are available between being exposed to physical punishment and depression or suicide probable in the future [15].

f) Instances of physical punishment encountered during early adolescence increase the probability of criminal and aggressive behaviors in students [23].

Punishment is a method used as the last resort in education. Physical punishment, however, is the harshest form of punishment imaginable. Research studies demonstrate that despite all its negative consequences, physical punishment has been frequently practiced across the world, as in Turkey $[24 ; 25 ; 26 ; 27 ; 28]$.

Even though teachers learn the negative influences of physical punishment on students during their pre-service training in various courses, they fail to apply the knowledge in real teaching settings. The tolerance of Turkish culture in physical punishment [29] as well as psychological, physical, economic and judicial factors may be influential in this situation. Teachers should not apply physical punishment whatever the reasons might be. They should perform right thing which is appropriate to humanity and education, rather than just doing what they presume right thing is. In an era when the whiteboards are as smart as computers, when will the teachers applying physical punishment on students become smart.

Applications of physical punishment on students in technical high schools by teachers in order to remove the undesired behaviors cause serious problems. Although the physical punishment applications practiced by teachers of technical high schools and their negative consequences appear in the media occasionally, it is still not sufficiently known what type of teachers apply that sort of punishment.

This research aims at determining whether or not technical course teachers' attitudes in technical high schools towards physical punishment differ on the basis of the socio-economic levels of the school they teach in, their teaching experience, gender, marital status, having or not having children, and the number of students in their classes.

\section{Method}

This study, which makes an attempt at determining technical course teachers' attitudes in technical high schools towards physical punishment on the basis of several variables, employs a review model, and is a descriptive study.

The research population was composed of the technical course teachers working in the technical high schools of the Ministry of Education in the provinces of Antalya, Isparta and Burdur. The sample, on the other hand, was composed of 160 technical course teachers working in 18 technical high 
schools, which were randomly chosen from the schools included in the research population and of which 6 were at low, 6 were at medium and 6 were at high socio-economic levels.

The scale of 'Opinions about Corporal Punishment', which was developed in the Likert method and which included 47 propositions was employed so as to reveal teachers' attitudes towards physical punishment. The Alpha reliability coefficient of the scale, which was translated into Turkish by Gözütok[4] was found to be 96 whereas Cronbach alpha reliability coefficient was found as .90 .

The SPSS 18.0 package program was employed in the statistical analyses of the data. The lowest score in the attitudes towards physical punishment scale was (0) while the highest was (47). In the statistical analyses for the independent groups, the t-test and variance analysis were used; and the Tukey test was used so as to find the source of difference arising in consequence of the variance analysis.

\section{Findings and Interpretations}

Firstly, whether vocational course teachers' attitudes in technical high schools towards corporal punishment differed according to the socio-economic environment of the school they work in, was analyzed. Table 1 presents the mean scores and standard deviations of each socio-economic level.

Table 1. The Scores of technical High School technical Course Teachers' Attitudes towards Corporal Punishment

\begin{tabular}{cccc}
\hline Groups & N & Mean & SD \\
\hline $\begin{array}{c}\text { Lower } \\
\text { socio-economic } \\
\text { level }\end{array}$ & 41 & 32.61 & 6.48 \\
$\begin{array}{c}\text { Medium } \\
\text { socio-economic } \\
\text { level }\end{array}$ & 57 & 30.16 & 8.75 \\
$\begin{array}{c}\text { High } \\
\text { socio-economic } \\
\text { level }\end{array}$ & 62 & 35.11 & 5.16 \\
Total & 160 & 32.62 & 6.79 \\
\hline
\end{tabular}

Variance analysis was conducted so as to find whether or not technical course teachers' attitudes differed or not on the basis of socio-economic environment of the schools they worked in. Table 2 shows the findings.

Table 2. The Results of Variance Analyses Concerning Corporal Punishment On the Basis of the Socio-economic Environment of the Schools Technical Course Teachers Work in

\begin{tabular}{cccccc}
\hline Source & SS & df & MS & F & P \\
\hline Between groups & 324.552 & 2 & 109.740 & & \\
Within groups & 12965.321 & 157 & 66.270 & 2.569 & $0.042^{*}$ \\
Total & 13289.873 & 159 & - & & \\
\hline
\end{tabular}

On examining the data shown in Table 2, differences were found between groups' attitudes towards physical punishment on the basis of the socio-economic environment of the schools $(\mathrm{F}=2.569, \mathrm{p}<.05)$. The Tukey test was conducted so as to determine the source of difference. The Tukey test results and the mean attitude scores in Table 1 demonstrated that there was a difference between the physical punishment scores of teachers working in schools located in the medium socio-economic level area and those working in schools located in high socio-economic level area in favor of high socio-economic level school teachers. This result might have stemmed from the fact that teachers working in high socio-economic level schools were more qualified and more experienced, they were competent in using the preventive model in workshop or classroom management, and that parents were more sensitive to physical punishment. In a research study concerning the frequency of physical punishment according to families' socio-economic levels performed [21], it was also found that physical punishment was applied less frequently with families of high socio-economic level while it was applied more frequently with families of low socio-economic level [30].

Secondly whether vocational course teachers' scores of attitudes towards corporal punishment differed according to their seniority in teaching was analyzed. Table 3 presents the mean scores and standard deviations of each category of teaching experience.

Table 3. The Technical Course Teachers' Scores of Attitudes towards Corporal Punishment According To Their Seniority in Teaching

\begin{tabular}{cccc}
\hline $\begin{array}{c}\text { Teaching } \\
\text { experience }\end{array}$ & $\mathrm{N}$ & Mean & SD \\
\hline 1-5 Years & 15 & 35.01 & 7.31 \\
6-10 Years & 20 & 36.13 & 9.35 \\
11-15 Years & 23 & 36.92 & 8.28 \\
16-20 Years & 29 & 37.13 & 5.43 \\
21-25 Years & 32 & 38.17 & 3.11 \\
26 Years and more & 41 & 33.71 & 9.01 \\
Total & 160 & 36.17 & 7.08 \\
\hline
\end{tabular}

In order to determine whether or not vocational high school technical course teachers' attitudes towards physical punishment differed according to their teaching experience, variance analysis was conducted and the findings were shown in Table 4.

Table 4. The Results of Variance Analyses Concerning Corporal Punishment On the Basis of Teachers' Experience

\begin{tabular}{cccccc}
\hline Source & SS & df & MS & F & P \\
\hline Between groups & 498.721 & 5 & 104.569 & & \\
Within groups & 13421.121 & 154 & 65.782 & 2.496 & $0.050^{*}$ \\
Total & 13919.984 & 159 & - & & \\
\hline
\end{tabular}

According to Table 4, significant differences were found between teachers' attitudes towards physical punishment on the basis of their teaching experience $(\mathrm{F}=2.496, \mathrm{p} \leq .05)$. The Tukey test results and the mean attitude scores in Table 3 demonstrated that there was a difference in favor of teachers with 21-25 year experience between 6-10 year experience, 
26 year or more experience group and 21-25 year experience group. The research findings obtained from Gözütok[4], Çiçekdemir[31], Başçı and Dilekmen[32], concerning primary school teachers also support our findings. This finding might also show that teachers with 26 year or more experience make up for their occupational knowledge inadequacy or hide their problems through such undesired behaviors by using physical punishment more than other groups despite their teaching experience. Therefore, seniority in teaching does not reduce physical punishment.

Thirdly, whether the vocational course teachers' scores of attitudes towards corporal punishment differed according to gender was analyzed. Table 5 presents the mean scores and standard deviations of male and female teachers and t-test results.

Table 5. The Technical Course Teachers' Scores of Attitudes towards Corporal Punishment According To Gender

\begin{tabular}{cccccc}
\hline Groups & N & Mean & SD & t & P \\
\hline Female & 99 & 37.02 & 7.82 & 1.102 & \\
Male & 41 & 35.72 & 8.85 & 0.25 & 0.25 \\
\hline
\end{tabular}

$\mathrm{p}>0,05$

The t-value of $1.102(\mathrm{p}>.05)$ demonstrates that there were no significant differences between vocational course teachers' towards physical punishment on the basis of gender. In research conducted by Gözütok[4] with primary school teachers, however, a difference was found in favor of female with regard to teachers' scores of attitudes towards physical punishment. Yet in research performed [32], no significant differences were found between primary school teachers' scores of attitudes towards physical punishment on gender basis. In line with those findings, it may be said that both male primary school teachers and male teachers teaching vocational courses in technical high schools began to receive attitude scores very close to those received by female teachers in terms of their attitudes towards physical punishment, and that positive changes are occurring in this issue.

Fourthly, whether the vocational course teachers' scores of attitudes towards corporal punishment differed according to marital status was analyzed. Table 6 presents the mean scores and standard deviations of each category of marital status.

Table 6. The Technical Course Teachers' Scores of Attitudes towards Corporal Punishment According To Marital Status

\begin{tabular}{cccc}
\hline Groups & N & Mean & SD \\
\hline Married & 119 & 34.70 & 8.40 \\
Single & 31 & 35.20 & 6.98 \\
Other & 10 & 39.40 & 2.23 \\
Total & 160 & 36.43 & 5.87 \\
\hline
\end{tabular}

In order to find out whether or not technical course teachers' attitudes towards physical punishment differed on the basis of marital status, variance analysis was conducted. The findings are shown in Table 7.
Table 7. The Results of Variance Analyses Concerning Corporal Punishment On the Basis of Marital Status

\begin{tabular}{cccccc}
\hline Source & SS & df & MS & F & P \\
\hline Between groups & 60.299 & 2 & 29.890 & & \\
Within groups & 12989.430 & 157 & 67.721 & 0.432 & 0.592 \\
Total & 13142.679 & 159 & - & & \\
\hline
\end{tabular}

As is clear from Table 7, no differences were found between technical course teachers' attitudes towards physical punishment on the basis of marital status $(\mathrm{F}=0.432$, $\mathrm{p}>.05$ ). This state showed that teachers' attitudes towards physical punishment did not change according to marital status.

Fifthly, whether the vocational course teachers' scores of attitudes towards corporal punishment differed according to whether or not having children was analyzed. Table 8 presents the mean scores and standard deviations of each category and t-test results.

Table 8. The Technical Course Teachers' Scores of Attitudes towards Corporal Punishment According To whether or Not Having Children

\begin{tabular}{cccccc}
\hline Groups & $\mathrm{N}$ & Mean & $\mathrm{SD}$ & $\mathrm{t}$ & $\mathrm{P}$ \\
\hline $\begin{array}{c}\text { Have children } \\
\begin{array}{c}\text { Doesn't have } \\
\text { children }\end{array}\end{array}$ & 132 & 34.787 & 8.32 & & \\
\hline
\end{tabular}

As is shown in Table 8, the t-value of 0.085 ( $p>.05$ ) failed to indicate no differences were found between teachers' attitudes towards physical punishment on the basis of whether or not having children. This state showed that teachers' attitudes towards physical punishment did not vary according to whether or not having children.

Finally, whether the vocational course teachers' scores of attitudes towards corporal punishment differed according to the number of students in classes was analyzed. Table 9 presents the mean scores and standard deviations of each class size.

Table 9. The Technical Course Teachers' Scores of Attitudes towards Corporal Punishment According To the Number of Students in Their Classes

\begin{tabular}{cccc}
\hline Groups & N & Mean & SD \\
\hline 20 and below & 95 & 37.01 & 7.10 \\
$21-30$ & 40 & 35.83 & 8.93 \\
$31-40$ & 25 & 36.72 & 7.12 \\
Total & 160 & 36.52 & 7.71 \\
\hline
\end{tabular}

Table 10. The Results of Variance Analyses Concerning Corporal Punishment On the Basis of the Number of Students in Classes

\begin{tabular}{cccccc}
\hline Source & SS & df & MS & F & P \\
\hline Between groups & 362.123 & 2 & 124.694 & & \\
Within groups & 12922.712 & 157 & 65.723 & 1.791 & 0.12 \\
Total & 13129.645 & 159 & - & & \\
\hline
\end{tabular}

Variance analysis was conducted so as to determine whether or not teachers' attitudes towards physical punishment differed according to the number of students in 
their classes. Table 10 shows the findings.

As can be seen from Table 10, no differences were found between teachers' attitudes towards physical punishment according to the number of students in classes in technical high schools $(\mathrm{F}=1.791, \mathrm{p}>.05)$. This result showed that teachers' attitudes towards physical punishment did not change according to the number of students in their classes.

\section{Conclusions and Recommendations}

Teachers working in vocational high schools located in areas of medium and low socio-economic levels apply more physical punishment on their students than those working in technical high schools located in areas of high socio-economic level. This is a finding parallel to the one obtained $[4 ; 32 ;]$, in relation to primary school teachers. In a similar vein, in research concerning the frequency of physical punishment according to families' socio-economic levels, found that physical punishment was less frequent with families of high socio-economic level but more frequent with families of low socio-economic level [30].

No significant differences were found between the scores of male and female teachers' attitudes towards physical punishment. The fact that male teachers' scores were close to the female teachers' scores showed that a positive change was occurring in favor of male teachers in terms of physical punishment.

Teachers with 26 year or more experience apply more physical punishment on students than those with less experience in vocational high schools. Even though application of physical punishment in technical high schools varies according to teachers' seniority, it still continues. This finding is similar to the one obtained from Gözütok[4], Çiçekdemir[31], Başçı and Dilekmen[32], Civelek[33] in their researches on primary school teachers. As their teaching experience increases teachers are able to make up for their "cognitive insufficiencies" at least in small amounts but they cannot control physical and emotional transformations arising through time and thus they tend to display undesired behaviors. That physical punishment applied in educational institutions of every level is not reduced according to teachers' seniority can be considered as one of the most significant obstacles in front of raising students of the desired properties.

No differences were found between technical teachers' attitudes towards physical punishment on the basis of marital status. This finding is similar to the one obtained from Çiçekdemir[31], Başçı and Dilekmen[32], Kundakçı[34] in their researches on primary school teachers.

No differences were found between technical teachers' attitudes towards physical punishment on the basis of whether or not having children or on the basis of the number of their children [32;34;35].

The maximum average score of attitudes towards physical punishment was 47 whereas the average for the teachers in the research was 34 . Teachers took the 13 points lesser than the maximum positive evaluation score from students. This state showed that teachers were not in a good position in terms of application of physical punishment on students.

1. More guidance should be given by educational authorities to teachers working in technical high schools located in areas of low and medium socio-economic levels in such issues as techniques of knowing students, student rights and democratic classroom management.

2. The Ministry of Education should encourage teachers with 26 year or more experience to retire.

3. High quality studies should be done in such issues as human rights, children's rights, individual freedom, the effects of physical punishment, violence and democratic classroom management in teacher training programs.

4. Parents and students should be informed of physical punishment so as to raise their sensitivity.

5. It should be assured that vehicles of mass media include research concerning the effects of physical punishment on students

6. Laws should be enforced on administrators and teachers applying physical punishment effectively, and it should be considered in appointment and promotion.

\section{REFERENCES}

[1] Erden, M. (2016). Introduction to Teaching Profession. İstanbul. Arkadaş Publishing.

[2] Başar, H. (2016). Classroom Management.18th Edition. Ankara. Anı Publishing.

[3] Mauzer.A (20001). Corporal punishment am.psychol. (Quoter: (NCCR NGOs coalition on child rights-Pakistan) Violence against children within the family and in schools committee on the rights of the child day of general discussion Friday, 28 September 2001 - OHCHR (Palais Wilson, Geneva).

[4] Gözütok D (1993). Whipping at schools. Ankara: 72 Offset Publishing.

[5] Benatar, D (2002). Corporal punishment. http://www.corpun.com/benatar.htm.

[6] Greydanus, D.E et al (2002). Corporal Punishments in Schools. http://www.adolescenthealth.org/html/corporal punishment in schools.html.

[7] Güven İ. (2004). Expectations from a teacher for an Effective Teaching. Education J. Ankara: Turkish Ministry of National Education. 164, pp.19-25

[8] Çalık, T. et al. (2016). Classroom Management and Characteristics (Ed: L. Küçükahmet). Classroom Management. Ankara: Nobel Publishing.

[9] Çetin Ş (2001). A study on Ideal Teacher. National Education 
J. Ankara. Ministry of Turkish National Education Publishing 149, pp.19-28

[10] Aydin A (2016). Classroom Management. Ankara. An1 Publishing.

[11] Sönmez V (2016). Teacher's handbook in program development. Ankara: Pegem publishing.

[12] Hollingworth, P.M \& Hoover, K. H. (1999). Elementary teaching methods. (Tran: Gürkan T, et al ). Ankara: Ankara University Publishing.

[13] Sunay Y (1997). Views of School Managers about students who get beating and teachers beating students In Primary Schools, 1st National Child Development Congress. Ankara: Turkish Ministry of National Education Pre-school Education Directorate General.

[14] Nelson, L. \& Glenn, S (2000). Positive discipline in classroom, (Tran: Koyuncu M). Hayat Publishing. İstanbul.

[15] Straus, Murray. (1995). Beating the devil out of them: Corporal punishment in American families. New York: Lexington books. (Quoter:Ramsburg, 1997. http://www.ed.gov/databases/ ERIC_ Digests/ ed405 139. html).

[16] Ramsburg, D (1997). The debate over spanking. ED405139, ERIC Clearinghouse on elementary and early childhood education Urbana IL http://www.ed.gov/databases/ ERIC_Digests/ed405139.html

[17] Christophersen, E R. (2000).The Pediatrician and Parental Discipline Pediatr,66.

[18] Mahiroğlu A. Buluç B (2003). Corporal Punishment Applications in Secondary schools. Turkish Educational Sciences J. 1(1), pp. 81-93.

[19] Barber, J.G. (1992). Evaluating parent education groups: Effects on sense of competence and social isolation. Research on Social Work Practice, 2. 28-38.

[20] Grusec, JE \& Goodnow, JJ (1994). Impact of parental discipline methods on the child's İnternalization of values: a reconceptualization of current points of view. Developmental psychology. 30, 4-19.

[21] Straus, M.A. et al (1997). Spanking by parents and subsequent antisocial behavior of children. Archives of pediatrics \& Adolescent medicine, 151, 761

[22] Sarıtaş M (2016). New approaches in classroom management ( Edt:Küçükahmet L.) Ankara Nobel publishing.
[23] Straus, M.A. (1994). Beating the devil out of them: Corporal punishment in American families. California: Lexington books.

[24] Bitensky, S. H. (2004) The constitutionality of school corporal punishment of children as a betrayal of brown board of education. Loyola University Chicago Law Journal, 36, 201-224.

[25] Check, J. F. ( 1979) Classroom discipline: Where are we now? Education 134.

[26] Crayn J. (1981) "Corporal Punishment in The Schools: Its Use İs Abuse" Educational Comment.

[27] Tan, M. (1990) "Eğitimde Bedensel Cezalandırma”. Eğitim Bilimleri Fakültesi Dergisi, Cilt: 23 Sayı.2 Ankara.

[28] Cooper H. Moore. W.L (2010) "Correlations, Between Teacher and Student, Background and Teacher Perception Of Discipline Problems and Disciplinary Techniques" Psychology in the schools.

[29] Akyüz, Y.(2016). Turkish Education History. Ankara. Pegem Akademi Publishing

[30] Bilgin A (2008). A study about intrafamilial physical Punishment. Ankara University Educational Sciences Faculty J. volume: 41, No: 31, 29-50

[31] Çiçekdemir G. (2003). Classroom teachers' attitude regarding Corporal Punishment, Adana: Çukurova University. Social Sciences Institute. Master Thesis.

[32] Başcı Z. Dilekmen, M. (2007) Analyse of classroom teachers' attitudes regarding corporal punishment in terms of several parameters. 16th Education Sciences Congress 5-7 October 2007 Gaziosmanpaşa University Education Faculty Tokat /Turkey.

[33] Civelek, K. (2001) İlköğretim sınıf öğretmenlerinin sınıf içi disiplini sağlamada kullandıkları yöntemler. (Yüksek lisans Tezi). Gazi Üniversitesi. Ankara.

[34] Kundakcı, B. (2002) İlköğretim okulları beşinci sınıf ögretmenlerinin cezayı tercih nedenlerine ilişkin tutumlarının çeşitli değişkenler açısından incelenmesi. (Yüksek Lisans Tezi).Abant İzzet Baysal Üniversitesi. Bolu.

[35] Erdoğan. Ş, Tarım K (2007). Teachers' attitude and behaviours towards the students whom they regard unsuccessful. Ankara: Turkish Educational J. Y1l:5 (1) 135-154. 